\title{
Highly Sensitive End-Point PCR and SYBR Green qPCR Detection of Phymatotrichopsis omnivora, Causal Fungus of Cotton Root Rot
}

M. Arif, S. Dobhal, P. A. Garrido, G. K. Orquera, and A. S. Espíndola, Department of Entomology and Plant Pathology, Oklahoma State University, Stillwater, USA; C. A. Young, Samuel Roberts Noble Foundation, Ardmore, OK, USA; F. M. Ochoa-Corona, S. M. Marek, and C. D. Garzón, Department of Entomology and Plant Pathology, Oklahoma State University, Stillwater, USA

\begin{abstract}
Arif, M., Dobhal, S., Garrido, P. A., Orquera, G. K., Espíndola, A. S., Young, C. A., Ochoa-Corona, F. M., Marek, S. M., and Garzón, C. D. 2014. Highly sensitive end-point PCR and SYBR green qPCR detection of Phymatotrichopsis omnivora, causal fungus of cotton root rot. Plant Dis. 98:1205-1212.

Phymatotrichopsis omnivora, the causal pathogen of cotton root rot, is a devastating ascomycete that affects numerous important dicotyledonous plants grown in the southwestern United States and northern Mexico. P. omnivora is notoriously difficult to isolate from infected plants; therefore methods for accurate and sensitive detection directly from symptomatic and asymptomatic plant samples are needed for disease diagnostics and pathogen identification. Primers were designed for $P$. omnivora based on consensus sequences of the nuclear ribosomal internal transcribed spacer (ITS) region of geographically representative isolates. Primers were compared against published $P$. omnivora sequences and validated against DNA from $P$. omnivora isolates and infected plant samples. The primer combinations amplified products from a range of $P$. omnivora isolates representative of known ITS haplotypes using standard end-point polymerase chain reaction (PCR)

methodology. The assays detected P. omnivora from infected root samples of cotton (Gossypium hirsutum) and alfalfa (Medicago sativa). Healthy plants and other relevant root pathogens did not produce PCR products with the $P$. omnivora-specific primers. Primer pair $\mathrm{PO} 2 \mathrm{~F} / \mathrm{PO} 2 \mathrm{R}$ was the most sensitive in end-point PCR assays and is recommended for use for pathogen identification from mycelial tissue and infected plant materials when quantitative PCR (qPCR) is not available. Primer pair PO3F/PO2R was highly sensitive $(1 \mathrm{fg})$ when used in SYBR Green qPCR assays and is recommended for screening of plant materials potentially infected by $P$. omnivora or samples with suboptimal DNA quality. The described PCR-based detection methods will be useful for rapid and sensitive screening of infected plants in diagnostic laboratories, plant health inspections, and plant breeding programs.
\end{abstract}

The soilborne fungus Phymatotrichopsis omnivora (Duggar) Hennebert causes root rots of important crops, such as cotton (Gossypium hirsutum L.), alfalfa (Medicago sativa L.), soybean (Glycine $\max$ (L.) Merr.), vegetable crops, and fruit and nut orchards, in the southwestern United States and northern Mexico. The common name of the disease is Phymatotrichopsis root rot, but it is also known as cotton root rot, Texas root rot, Ozonium root rot, and Phymatotrichum root rot. The disease was first reported in the late $1880 \mathrm{~s}(26,27)$ and has since remained of considerable economic concern, causing up to $\$ 100$ million in annual losses to the U.S. cotton crop alone. The average loss of raw cotton fiber yield has been estimated to be $3.5 \%$ in Texas and 2.2\% in Arizona, with losses ranging from 8 to $13 \%$ in severely infested areas $(15,22,33)$. $P$. omnivora has a large host range that includes around 2,000 species of dicotyledonous plants (31). Initial root infection occurs when soil temperatures and moisture rise in late spring to early summer and is usually symptomless. However, after the roots are girdled by the resulting rot and soil moisture decreases later in the summer, plants quickly wilt and almost inevitably die, usually forming circular patterns of wilting and dead plants in the field that progressively expand to form large patches (Fig. 1). Due to its potentially high economic impact, broad host range, and limited geographic range, $P$. omnivora is included on the quarantined/

Corresponding authors: C. D. Garzón, E-mail: carla.garzon@okstate.edu and S. M. Marek, E-mail: stephen.marek@okstate.edu

\footnotetext{
* The $\boldsymbol{e}$-Xtra logo stands for "electronic extra" and indicates that Figure 1 appears in color in the online edition.
}

Accepted for publication 17 January 2014.

http://dx.doi.org/10.1094/PDIS-05-13-0505-RE

(C) 2014 The American Phytopathological Society regulated pest lists of many organizations, including the European and Mediterranean Plant Protection Organization $(11,25)$, the California Department of Food and Agriculture (8), the Australian Cotton Research Institute (3), and the United Nations Security Council's monitoring program of Iraq (32).

Rapid and accurate detection of plant pathogens is important for timely implementation of disease management. Nucleic acid based techniques, especially those that rely on the polymerase chain reaction (PCR), are among the most widely used techniques for plant pathogen detection $(17,34)$. PCR allows reliable and sensitive microbial detection in surveillance programs. Real-time quantitative PCR (qPCR) can be used for both detection and quantification of plant pathogens $(17,23)$ and, due to its use of fluorescence, is up to 100 times more sensitive than end-point PCR and can detect down to a single fungal spore (Glomus intraradices) (2). Among qPCR formats, TaqMan and SYBR Green qPCRs are the two most popular (7). SYBR Green qPCR is relatively inexpensive and more suitable for routine and large-scale monitoring and surveillance $(6,14,19,20,28)$.

This research addresses the development of end-point and SYBR Green qPCR assays for isolate identification and for detection and/or monitoring of the root rot pathogen $P$. omnivora directly from infected plant tissues.

\section{Materials and Methods}

Samples. Information regarding fungal strains and plants used in this study are summarized in Table 1. Sixteen Phymatotrichopsis omnivora isolates from cotton and alfalfa, isolated as previously described (22), were used in validation tests. These isolates were collected from locations in Arizona, Texas, and Oklahoma. Isolates of fungal soilborne pathogens isolated from $P$. omnivora known hosts, Rhizina undulata Fr., P. omnivora's closest known relative, healthy tissues from host and common rotation crops, commercial Jiffy Seed Starting Mix (Ferry Morse Seed Co., Fulton, KY), and loam soil from a location outside of the geographic distribution of 
P. omnivora (OSU Agronomy Research Station, Stillwater, OK) were included in specificity tests (Table 1). Isolation and culture of P. omnivora, Pythium aphanidermatum, and Sclerotinia minor were performed as previously reported $(1,22,24)$. Pure cultures of Fusarium solani, Neocosmospora vasinfecta, Macrophomina phaseolina, Colletotrichum truncatum, and Acrostalagmus luteoalbus were obtained from the fungal collection maintained at the Oklahoma State University, grown on potato dextrose agar (PDA) for 5 days at room temperature, then transferred to potato dextrose broth (PDB) and grown for 5 to 7 days at room temperature before harvesting. Dried $R$. undulata apothecia and cultures of Rhizoctonia solani and Sclerotinia minor were provided by other researchers.

Samples of 37 symptomatic and apparently healthy alfalfa (Ardmore, OK) and cotton (Altus, OK) were obtained for protocol validation using field samples of the standard GoTaq end-point
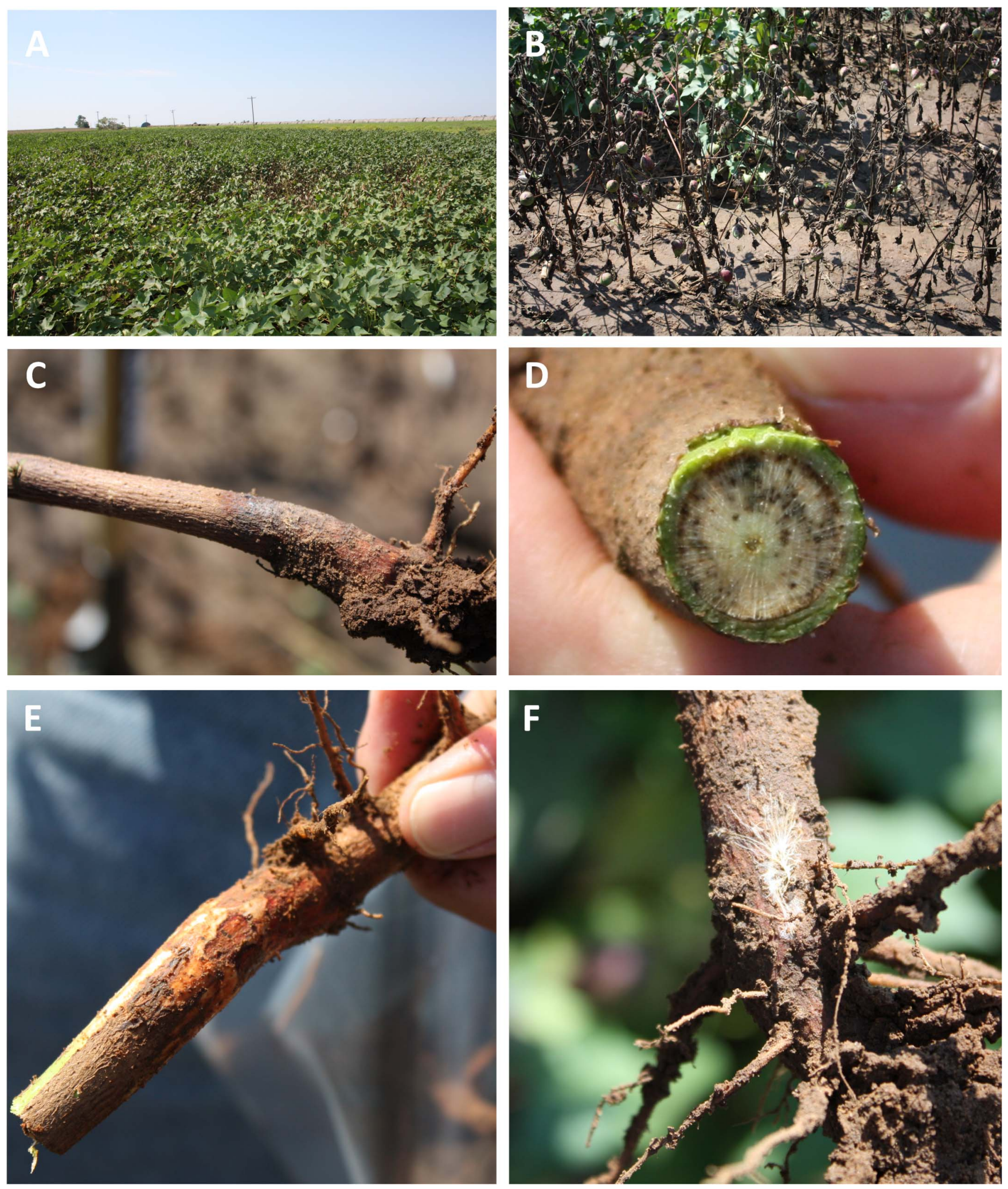

Fig. 1. Cotton root rot symptoms and signs. A, Disease focus visible in otherwise healthy field. B, Wilt and necrotic plants due to root rot. C, Mycelial growth on the surface of plant crown. D, Vascular discoloration. E, Cortical lesion under scraped epidermis near plant crown. F, Hyphae and sclerotia may be present on crown surface. 
PCR assay and the SYBR Green qPCR assay (Table 2). Pure culture isolation of $P$. omnivora from these samples was performed as reported previously (22). Also, samples of symptomatic or apparently healthy alfalfa, cotton, and soybean collected in Texas, Arizona, and Oklahoma ( $n=148$; Table 3$)$ were used for validation with field samples of the modified GoTaq end-point PCR assay using primer set $\mathrm{PO} 3 \mathrm{~F} / \mathrm{PO} 2 \mathrm{R}$. Alfalfa and cotton seedlings used as noninoculated negative controls were grown from seed for 7 days in growth chambers at $28^{\circ} \mathrm{C}, 80 \%$ relative humidity, and under 12 $\mathrm{h}$ of light.

DNA isolation. DNA from $P$. omnivora, F. solani, A. luteoalbus, M. phaseolina, $C$. truncatum, N. vasinfecta, $R$. solani, $P$. aphanidermatum, and $R$. undulata mycelia, healthy plant tissues (Table 1), 37 cotton and alfalfa field samples (Table 2), and from Jiffy

Table 1. Fungal and healthy plant samples used in this study

\begin{tabular}{|c|c|c|c|}
\hline Species & Sample ID & Host plant & Origin/source \\
\hline Phymatotrichopsis omnivora & NFAlf-7 & Alfalfa & Carter Co., OK \\
\hline P. omnivora & OKAlf-8 & Alfalfa & Love Co., OK \\
\hline P. omnivora & PECOS TXAlf 07-2a & Alfalfa & Reeves Co., TX \\
\hline P. omnivora & SANE TXC07-10 & Cotton & Tom Green Co., TX \\
\hline P. omnivora & Braden TXC07-6 & Cotton & Pecos Co., TX \\
\hline P. omnivora & FS TXAlf07-1 & Alfalfa & Pecos Co., TX \\
\hline P. omnivora & TAMD C05-3 $3^{\mathrm{a}, \mathrm{b}}$ & Cotton & Collin Co., TX \\
\hline P. omnivora & EC $59 \mathrm{C}^{2} 5^{\mathrm{a}}$ & Cotton & Wharton Co., TX \\
\hline P. omnivora & EC 358 C $05-4$ & Cotton & Wharton Co., TX \\
\hline P. omnivora & Rick C05-5 & Cotton & Refugio Co., TX \\
\hline P. omnivora & Trumbull C05-4a & Cotton & Ellis Co., TX \\
\hline P. omnivora & Maud Lowe C05-1 ${ }^{\mathrm{a}}$ & Cotton & Refugio Co., TX \\
\hline P. omnivora & Yuma 2 AZC07-7a & Cotton & Yuma Co., AZ \\
\hline P. omnivora & CCAZAlf07-2 & Alfalfa & Maricopa Co., AZ \\
\hline P. omnivora & Marana AZC07-4 & Cotton & Pima Co., AZ \\
\hline P. omnivora & MS AZC07-4 & Cotton & Pima Co., AZ \\
\hline Rhizina undulata & Rhizina-1 & $\ldots$ & Sweden \\
\hline Sclerotinia minor & Sminor-9 & Peanut & Stillwater, OK \\
\hline Fusarium solani & NFAlf & Alfalfa & Ardmore, OK \\
\hline Macrophomina phaseolina & AlfMC-11 & Alfalfa & Belleville, OK \\
\hline Colletotrichum truncatum & OSUAlf & Alfalfa & Stillwater, OK \\
\hline Acrostalagmus luteoalbus & Vt. 2 cherry leaf & Cherry & Davis, CA \\
\hline Neocosmospora vasinfecta & AlfMC-3 & Alfalfa & Belleville, OK \\
\hline Rhizoctonia solani & RS7 & Unknown & Jennifer Olson, OSU, OK \\
\hline Pythium aphanidermatum & P18 & Poinsettia & Gary Moorman, PSU, PA \\
\hline Medicago sativa & $\ldots$ & Alfalfa & Stillwater, OK \\
\hline Gossypium hirsutum & $\ldots$ & Cotton & Stillwater, OK \\
\hline Sorghum bicolor & $\ldots$ & Sorghum & Stillwater, OK \\
\hline Triticum aestivum & $\ldots$ & Wheat & Stillwater, OK \\
\hline Arachis hypogaea & $\ldots$ & Peanut & Stillwater, OK \\
\hline Glycine max & $\ldots$ & Soybean & Stillwater, OK \\
\hline Zea mays subsp. mays & $\ldots$ & Corn & Stillwater, OK \\
\hline Potting mix & $\ldots$ & $\ldots$ & Stillwater, OK \\
\hline Loam soil & $\ldots$ & $\ldots$ & Stillwater, OK \\
\hline
\end{tabular}

a Isolates used to compare standard and modified end-point polymerase chain reaction (PCR) protocols.

${ }^{\mathrm{b}}$ Isolate used to assess standard end-point PCR assay sensitivity.

Table 2. Comparison of GoTaq Green (GTG) end-point polymerase chain reaction (PCR) and quantitative PCR (qPCR) protocols using field samples collected at two Oklahoma locations in $2012^{\mathrm{a}}$

\begin{tabular}{|c|c|c|c|c|c|}
\hline Sample name ${ }^{b}$ & Field site & Host plant & No. samples & $\begin{array}{l}\text { PCR positives } \\
\text { PO/ITS }\end{array}$ & $\begin{array}{l}\text { qPCR positives } \\
\text { (estimated concentrations) }\end{array}$ \\
\hline ALF-P1 & Field 1, Ardmore, OK & Alfalfa & 3 & $0 / 1$ & 3 (4.7 ng; 29 pg; $3.6 \mathrm{ng})$ \\
\hline ALF-P2 & Field 2, Ardmore, OK & Alfalfa & 3 & $0 / 1$ & $3(6.5 \mathrm{pg} ; 63 \mathrm{fg} ; 3 \mathrm{fg})$ \\
\hline ALF-P3 & Field 3, Ardmore, OK & Alfalfa & 3 & $0 / 3$ & $3(245 \mathrm{fg} ; 4.4 \mathrm{pg} ; 92 \mathrm{fg})$ \\
\hline ALF-R1 & Field 1, Ardmore, OK & Alfalfa & 3 & $0 / 2$ & $3(193 \mathrm{fg} ; 2.5 \mathrm{ng} ; 499 \mathrm{pg})$ \\
\hline ALF-R2 & Field 2, Ardmore, OK & Alfalfa & 3 & $0 / 3$ & $3(1.8 \mathrm{pg} ; 198 \mathrm{fg} ; 88 \mathrm{fg})$ \\
\hline ALF-R3 & Field 3, Ardmore, OK & Alfalfa & 3 & $3 / 3$ & $3(58 \mathrm{pg} ; 44 \mathrm{pg} ; 8 \mathrm{pg})$ \\
\hline ALF-H1 & Field 1, Ardmore, OK & Alfalfa & 3 & $0 / 2$ & $3(23 \mathrm{fg} ; 27 \mathrm{fg} ; 2.5 \mathrm{pg})$ \\
\hline ALF-H2 & Field 2, Ardmore, OK & Alfalfa & 3 & $3 / 3$ & $3(39 \mathrm{pg} ; 3.9 \mathrm{pg} ; 4.4 \mathrm{pg})$ \\
\hline ALF-H3 & Field 3, Ardmore, OK & Alfalfa & 3 & $0 / 3$ & $3(34 \mathrm{fg} ; 266 \mathrm{fg} ; 280 \mathrm{fg})$ \\
\hline Cott-H & Altus, OK & Cotton & 4 & $4 / 4$ & $4(36 \mathrm{pg} ; 91 \mathrm{fg} ; 2.9 \mathrm{fg} ; 18 \mathrm{pg})$ \\
\hline Cott-P & Altus, OK & Cotton & 3 & $1 / 1$ & $3(>10 \mathrm{ng} ;>10 \mathrm{ng} ;>10 \mathrm{ng})$ \\
\hline Cott-R & Altus, OK & Cotton & 3 & $2 / 1$ & $3(978 \mathrm{pg} ;>10 \mathrm{ng} ;>10 \mathrm{ng})$ \\
\hline Cott-N & Growth chamber, Stillwater, OK & Cotton & 1 & $0^{\mathrm{d}}$ & 0 \\
\hline ALF-N & Growth chamber, Stillwater, OK & Alfalfa & 1 & $0^{\mathrm{d}}$ & 0 \\
\hline Total & & & 39 & $13 / 27$ & 37 \\
\hline
\end{tabular}

${ }^{a}$ Field samples assayed with GTG end-point PCR using Phymatotrichopsis omnivora specific primer set PO2F/PO2R (PO) were also assayed with universal primers ITS4/ITS5 to identify false positives and false negatives. The qPCR protocol used primer set PO3F/PO2R.

${ }^{\mathrm{b}} \mathrm{ALF}=$ alfalfa; Cott $=$ cotton $; \mathrm{H}=$ healthy looking root tissue; $\mathrm{P}=$ partially rotted root tissues; $\mathrm{R}=$ fully collapsed, rotted root tissue; $\mathrm{N}=$ noninoculated negative controls.

c All the samples positive for universal ITS primers but negative for $P$. omnivora specific primers produced sequences of either the host plant or fungi other than P. omnivora.

d Assayed with PO2F/PO2R only. 
Seed Starting Mix (Ferry Morse Seed Co.) was isolated using DNeasy Plant Mini Kit (Qiagen Inc., Valencia, CA). DNA from 148 field samples (Table 3) was extracted from approximately 20 mg of lyophilized root samples using the MagAttract 96 DNA Plant Kit (Qiagen). DNA extraction from Sclerotinia minor was performed as previously reported (1). DNA from loam soil was isolated using a Soil Extraction Kit (MoBio, Carlsbad, CA).

DNA sequence analysis and primer design. The internal transcribed spacer (ITS) regions of 125 P. omnivora isolates, obtained for a population biology study that will be reported elsewhere, were amplified using ITS region specific primer set ITS4/ITS5 (34) and conditions described by Marek et al. (22). These isolates were isolated from diverse locations in the United States (Texas, Oklahoma, and Arizona) and the North of Mexico, representing the genetic diversity of the species across its geographic range (21). PCR products were purified using PureLink PCR Purification Kit (Invitrogen Inc., Carlsbad, CA) and sequenced using an Applied Biosystems DNA 3730 Analyzer (Oklahoma State University Nucleic Acids and Proteins Core Facility). The 125 ITS sequences obtained and 19 additional $P$. omnivora accessions retrieved from the National Center for Biotechnology Information (NCBI) GenBank database (http://www.ncbi.nlm.nih.gov/genbank/) were aligned using CLUSTALX v. 2 (18). Sequence alignments errors were corrected manually and conserved regions were identified using percent identity matrices in GeneDoc (Genedoc, a Tool for Editing and Annotating Multiple Sequence Alignments. 1997. K. B. Nicholas, H. B. Nicholas Jr., and D. W. Deerfield II. Distributed by the author.). PCR primers for P. omnivora (Table 4) were designed based on the consensus of aligned sequences using Primer3 (29). The presence of internal secondary structures and homo- and self-dimers in the primers was examined using mFold (35).

Preparation of plasmid positive controls and qPCR standards. PCR products amplified from genomic DNA of $P$. omnivora isolate EC 358 C05-4 (Table 1) with each of three P. omnivoraspecific primer sets were gel purified using Quantum Prep Freeze 'N Squeeze Spin Columns (Bio-Rad Laboratories, Hercules, CA) and cloned into a plasmid vector (pCR2.1-TOPO) using a TOPOTA Cloning Kit (Invitrogen). Plasmid DNA was purified from overnight bacterial cultures using a QIAprep Spin Miniprep Kit (Qiagen). Isolated plasmid DNA was quantified using a NanoDrop v. 2000 spectrophotometer (Thermo Fisher Scientific Inc., Waltham, MA) and sequenced. Plasmids containing PCR products were used in sensitivity tests, as positive controls, and as standards for qPCR.

End-point PCR assay development. The GoTaq Green (GTG) Master Mix (Promega, Madison, WI) was used in end-point PCR assays using primer set PO1F/PO1R with the reaction conditions and temperature cycling parameters recommended by the manufacturers, since it consistently produced superior results (data not shown) in preliminary comparisons between that kit and the Takara Taq kit (Takara Bio Inc., Shiga, Japan). Additionally, a modification of the standard GoTaq Green Master Mix (MGTG) protocol was evaluated for smaller reaction volumes and shorter temperature cycling times (i.e., total $\mathrm{PCR}$ program run for $\mathrm{PO} 2 \mathrm{~F} /$ PO2R was 38 min with MGTG compared to 78 min with GTG). In the MGTG protocol reactions were $20 \mu \mathrm{l}(10 \mu \mathrm{l}$ master mix, $10 \mathrm{ng}$ template, and $1 \mu \mathrm{l}$ of each $5 \mu \mathrm{M}$ primer), and the thermocycling protocol included an initial denaturation of $3 \mathrm{~min}$ at $95^{\circ} \mathrm{C}$, followed by 30 (PO1F/PO1R and PO2F/PO2R) or $35(\mathrm{PO} 3 \mathrm{~F} /$ $\mathrm{PO} 2 \mathrm{R}$ ) cycles of $20 \mathrm{~s}$ denaturation at $94^{\circ} \mathrm{C}, 15 \mathrm{~s}$ annealing (annealing temperatures reported in Table 4), and $20 \mathrm{~s}$ extension at $72^{\circ} \mathrm{C}$, and final extension at $72^{\circ} \mathrm{C}$ for $3 \mathrm{~min}$.

SYBR Green qPCR assay development. Reactions $(20 \mu \mathrm{l})$ contained $10 \mu \mathrm{l}$ of Platinum SYBR Green qPCR SuperMix-UDG (Invitrogen, Grand Island, NY), $0.8 \mu \mathrm{l}(5 \mu \mathrm{M})$ of each forward and reverse primer, $1 \mu \mathrm{l}$ of template genomic DNA (various DNA concentrations), and $7.4 \mu \mathrm{l}$ of nuclease-free water (Ambion, Austin, TX). Positive (plasmid carrying the target gene sequence or $P$. omnivora genomic DNA) and negative (nontarget template or water) controls were included in each set of qPCR assays. Each reaction was performed in triplicate. Cycling parameters included two initial holds at $50^{\circ} \mathrm{C}$ and $95^{\circ} \mathrm{C}$, each for $2 \mathrm{~min}$, and 40 cycles of $95^{\circ} \mathrm{C}$ for $15 \mathrm{~s}$, and $60^{\circ} \mathrm{C}$ for $60 \mathrm{~s}$. The assays were performed in a Rotor-Gene 6000 thermocycler (Corbett Research, Sydney, Australia).

End-point PCR sensitivity test. The detection limits of each of the three primer sets when used with the GTG and MGTG proto-

Table 3. Efficiency of the modified GoTaq Green (MGTG) end-point polymerase chain reaction (PCR) protocol to detect Phymatotrichopsis omnivora DNA in cotton, alfalfa, and soybean, root samples collected from Phymatotrichopsis root rot affected sites in 2009 and research plots with primer set PO3F/PO2R

\begin{tabular}{|c|c|c|c|c|}
\hline Sample name & Field site & Host plant/substrate & Total samples & P. omnivora positive \\
\hline Liberty 1 & Field 1, Bryan Co., OK & Alfalfa & 3 & 3 \\
\hline Liberty 2 & Field 1, Bryan Co., OK & Alfalfa & 10 & 10 \\
\hline Liberty 3 & Field 1, Bryan Co., OK & Alfalfa & 10 & 10 \\
\hline Liberty 4 & Field 1, Bryan Co., OK & Alfalfa & 8 & 8 \\
\hline Liberty 5 & Field 1, Bryan Co., OK & Alfalfa & 10 & 9 \\
\hline Liberty 1 Soy & Field 1, Bryan Co., OK & Soybean & 10 & 9 \\
\hline ELRD 1 & Field 2, Bryan Co., OK & Alfalfa & 10 & 10 \\
\hline Deport 1 & Field 3, Red River Co., TX & Cotton & 10 & 6 \\
\hline Deport $2 \mathrm{G}^{\mathrm{a}}$ & Field 4, Red River Co., TX & Cotton & 10 & 0 \\
\hline Deport $2 \mathrm{~N}^{\mathrm{a}}$ & Field 4, Red River Co., TX & Cotton & 5 & 0 \\
\hline Deport 2 & Field 4, Red River Co., TX & Cotton & 10 & 1 \\
\hline Deport $2 \mathrm{~W}$ & Field 4, Red River Co., TX & Cotton & 10 & 4 \\
\hline Plant RSYD4 LLA ${ }^{\mathrm{b}}$ & Greenhouse, Carter Co., OK & Alfalfa & 20 & 19 \\
\hline Plant 19 and $21 \mathrm{CCOMT}^{\mathrm{b}}$ & Greenhouse, Carter Co., OK & Alfalfa & 15 & 13 \\
\hline OKAlf $^{c}$ & Laboratory strain & Sterile wheat grain & 7 & 7 \\
\hline Total & & & 148 & 109 \\
\hline \multicolumn{5}{|c|}{$\begin{array}{l}\text { a Healthy looking plants. } \\
\text { b Plants inoculated with } P \text {. omnivora OKAlf8. } \\
{ }^{c} \text { Pure culture used as positive control. }\end{array}$} \\
\hline Primer name & Primer sequence $\left(5^{\prime}-3^{\prime}\right)$ & Primer location & & aling temp. $\left({ }^{\circ} \mathrm{C}\right)$ \\
\hline PO1F & CAAATGGATGCCCGTAGT & ITS1 & & 58.5 \\
\hline PO1R & CCAATGACCAAGCCAACC & ITS2 & & 58.5 \\
\hline $\mathrm{PO} 2 \mathrm{~F}$ & AAACCCCCAAATGGATGC & ITS1 & & 60.0 \\
\hline $\mathrm{PO} 2 \mathrm{R}$ & CACCACCATACTACGTCAAAGG & ITS2 & & 60.0 \\
\hline $\mathrm{PO} 3 \mathrm{~F}$ & CGAGCGTCAGCATAACAAAA & 5.8S rDNA, ITS2 & & 60.0 \\
\hline
\end{tabular}


cols were determined by conducting PCR reactions using 10-fold dilutions (10 ng to $1 \mathrm{ag}$ ) of genomic DNA of $P$. omnivora isolate TAMD C05-3 (Table 1).

SYBR Green qPCR sensitivity test. Sensitivity of the qPCR assay was evaluated using 10-fold dilutions of plasmid DNA containing cloned PO3F/PO2R PCR product, genomic DNA, or genomic DNA mixed with host plant DNA. To simulate interference from host plant DNA, $1 \mathrm{ng}$ genomic DNA from healthy alfalfa or healthy cotton was added to each reaction in addition to 10-fold dilutions of genomic DNA from P. omnivora isolate TAMD C05-3 at concentrations from $1 \mathrm{ng}$ to $1 \mathrm{ag}$ per reaction. Each qPCR sensitivity test was replicated three times.

Primer specificity test. The specificity of the three primer sets was challenged using genomic DNA of fungal plant pathogens, the nonpathogenic fungus Rhizina undulata, healthy plants, or obtained from soil and potting mix (Table 1) using the MGTG protocol. To confirm that targeted gene sequences were amplified in the PCR assays, amplicons obtained with the three primer sets from genomic DNA (10 ng) of P. omnivora isolate EC 358 C05-4 (Table 1) were directly sequenced using the same forward and reverse primers. BLASTn (4) was used to compare the amplicon sequences against the GenBank database.

End-point PCR protocol validation. Three end-point PCR validation experiments were conducted. In the first experiment, the three primer sets were tested on $16 P$. omnivora isolates representing the genetic diversity of the fungus in Texas, Oklahoma, and Arizona (Table 1), using the MGTG protocol. In the second experiment, the utility of the GTG protocol using primer set PO2F/PO2R for detection of $P$. omnivora during routine tests was assessed using DNA samples of 37 symptomatic (alfalfa $=18$; cotton $=6$ ) (Table 2), and apparently healthy plants (alfalfa $=9$; cotton $=4)$ that had the risk of having latent infections due to their proximity to symptomatic plants in the field. The DNA samples used in this experiment varied in quality (DNA $260 / 280$ ratio 0.9 to 2.2 ) and were not further purified to test the primers in reactions with suboptimal DNA quality. Positive (TAMD C05-3 genomic DNA; Table 1) and negative (noninoculated cotton and alfalfa) controls were included. In order to identify false negatives (infected but not amplified), the same samples were assayed with ITS-region-specific universal primers ITS4 and ITS5 (34). The PCR products obtained with primer sets PO2F/PO2R and ITS4/ITS5 (Table 2) were directly sequenced, and their sequences were blasted against the GenBank database.

Finally, the MGTG protocol was validated using primer set PO3F/PO2R and DNA isolated from 148 samples (DNA 260/280 ratio $>1.7)$ comprised of symptomatic alfalfa $(n=86)$, cotton $(n=$ $30)$, and soybean $(n=10)$, and apparently healthy cotton $(n=15)$ collected from Texas, Arizona, and Oklahoma, and one laboratory isolate originally collected from an infested alfalfa field in Oklahoma (Table 3).

SYBR Green qPCR protocol validation. The SYBR Green qPCR protocol was validated using the 37 plant DNA samples and controls used in the validation of GTG end-point PCR assay (Table 2). DNA was diluted to a final concentration of $2 \mathrm{ng} / \mu \mathrm{l}$, but was not further purified. Each qPCR reaction was carried out in a total volume of $15 \mu \mathrm{l}(7.5 \mu \mathrm{l}$ of FastStart SYBR Green Master [Roche Applied Sciences, Indianapolis, IN], $0.45 \mu \mathrm{l}$ of PO3F primer at 5 $\mu \mathrm{M}, 0.45 \mu \mathrm{l}$ of PO2R primer at $5 \mu \mathrm{M}$, and $6.6 \mu \mathrm{l}$ (13.2 ng) DNA) in a MyiQ real-time PCR detection system (Bio-Rad). Amplification conditions were: one cycle of $20 \mathrm{~s}$ at $95^{\circ} \mathrm{C}$, followed by 55 cycles of $15 \mathrm{~s}$ at $94^{\circ} \mathrm{C}, 15 \mathrm{~s}$ at $60^{\circ} \mathrm{C}$, and $20 \mathrm{~s}$ at $72^{\circ} \mathrm{C}$. Positive (isolate TAMD C05-3 genomic DNA) and negative controls (healthy alfalfa and cotton seedlings; PCR grade water) were included. All the reactions were performed with three replicates. The standard curve was calculated using 10 -fold serial dilutions of $P$. omnivora isolate TAMD C05-3 genomic DNA, between $10 \mathrm{ng} / \mu \mathrm{l}$ and $100 \mathrm{ag} / \mu \mathrm{l}$.

\section{Results}

Primer design and PCR assay development. Primer design. Three sets of PCR primers (PO1F/PO1R, PO2F/PO2R, and
PO3F/PO2R) were designed (Table 4). All primers annealed to conserved regions of the consensus sequence (Fig. 2). Primer sequences, positions, and annealing temperatures are shown in Table 4. Primer sets $\mathrm{PO} 1 \mathrm{~F} / \mathrm{PO} 1 \mathrm{R}, \mathrm{PO} 2 \mathrm{~F} / \mathrm{PO} 2 \mathrm{R}$, and $\mathrm{PO} 3 \mathrm{~F} / \mathrm{PO} 2 \mathrm{R}$ produced PCR products approximately $451 \mathrm{bp}, 564 \mathrm{bp}$, and $168 \mathrm{bp}$ long, respectively (Fig. 2). Because of its small PCR product size, primer set PO3F/PO2R was compatible with SYBR Green qPCR.

Determination of primer specificity. Primers PO1F, PO1R, $\mathrm{PO} 2 \mathrm{~F}, \mathrm{PO} 2 \mathrm{R}$, and PO3F were blasted against NCBI's GenBank nucleotide database. All the primers showed $100 \%$ query coverage and $100 \%$ identity with $P$. omnivora accessions exclusively, and no other $100 \%$ coverage and high-identity $(>90 \%)$ hits were observed. The three primer sets did not produce PCR products with DNA from healthy plants, noninoculated potting mix, or soil samples, or from oomycete and fungi other than $P$. omnivora (Table 1).

Sensitivity of end-point PCR assays. The GTG protocol was 10 times more sensitive than the MGTG protocol with primer set $\mathrm{PO} 2 \mathrm{~F} / \mathrm{PO} 2 \mathrm{R}$, but similar in sensitivity with primer sets PO1F/PO1R and PO3F/PO2R (Fig. 3). The detection limits of primer sets $\mathrm{PO} 1 \mathrm{~F} / \mathrm{PO} 1 \mathrm{R}, \mathrm{PO} 2 \mathrm{~F} / \mathrm{PO} 2 \mathrm{R}$, and $\mathrm{PO} 3 \mathrm{~F} / \mathrm{PO} 2 \mathrm{R}$ with the GTG protocol were $100 \mathrm{pg}, 100 \mathrm{fg}$, and $10 \mathrm{pg}$ P. omnivora genomic DNA per reaction, respectively (Fig. 3). The detection limits of primer sets $\mathrm{PO} 1 \mathrm{~F} / \mathrm{PO} 1 \mathrm{R}, \mathrm{PO} 2 \mathrm{~F} / \mathrm{PO} 2 \mathrm{R}$, and $\mathrm{PO} 3 \mathrm{~F} / \mathrm{PO} 2 \mathrm{R}$ with the MGTG protocol were $100 \mathrm{pg}, 1 \mathrm{pg}$, and $10 \mathrm{pg}$ P. omnivora genomic DNA per reaction, respectively (Fig. 3). Primer set $\mathrm{PO} 2 \mathrm{~F} / \mathrm{PO} 2 \mathrm{R}$ was consistently more sensitive than the other two primer sets, followed by primer set PO3F/PO2R (Figs. 3 and 4). Since PO1F/PO1R was the least sensitive primer set, field validation test results for this primer set were not included in this report.

Sensitivity of SYBR Green $q P C R$. The qPCR assay with the $\mathrm{PO} 3 \mathrm{~F} / \mathrm{PO} 2 \mathrm{R}$ primer set was 10,000 -fold more sensitive than the end-point PCR assay with the same primer set when genomic DNA was tested (Fig. 4, Table 5). The generated standard curve showed $R^{2}$ values between 0.985 and 0.999 , and reaction efficiency values of 1.01 and 1.23 (Table 5). A threshold (statistical significant point above the calculated baseline fluorescence) of 0.2 was used to compare the standard curves generated for assays using plasmid, genomic, and mixed genomic DNA as templates. The PO3F/PO2R

A

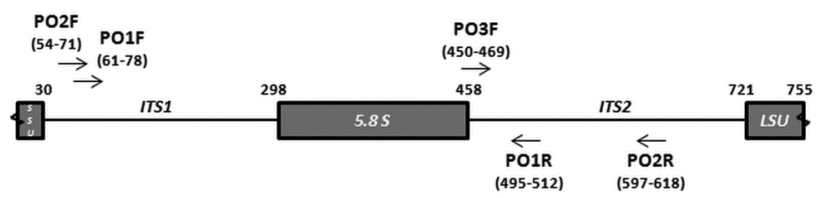

B 1 CCGTAGGTGAACCTGCGGAAGGCATCATTAAAGGAGGCACGGGCGAAAAT 51 AAAAAACCCCCAAATGGATGCCCGTAGTCCTATATAAACCTATCAGTGTA $(\mathrm{PO} 2 \mathrm{E})>>>>>>>>>>>>>>>>>$

$(\mathrm{PO} 1 \mathrm{~F})>>>>>>>>>>>>>>>>>$

101 CCTCTCCACGTTGCTTCCGTGTGGCCCAGGGGGCTTTGGCCAGCGATGCC

151 GGCTCCGCGGGTTTTCCGGCCCCCCCCCCCCCTCCCCAATTTGTTGTGGG

201 GGCTCCGCGGGTTTCCGGCCCCCCCCCCCCCTCCCCAATTTGTTGTGGG

201 GGGGTGGGTTGTGCCCGGCCCACGGGAGGAATTCTCCAAACTCTTGATTG

301 AAAAAAAAAAGAACGTATGCCMTATATATAAAGAGAAAAAAAAATGGTTT

351 GCGAAATGCGATAAGTAAT GT GAATTGCAGAATTCAGGT GAATCATCGAA

401 TCTTTGAACGCACATTGCGCCCTCCGGTATTCCGGAGGGCATGCCTGTTC

(PO3F) $>$
GAGCGTCAGCATAACAAAACCTCAAGGCACCCTTGTGAAAGAGGGTGG 501 CTTGGTCATTGGCGTGGTAGGGGCGATTTGCGTGCCCCTACTCTGCTG $<<<<<<<<<<<<(P O 1)$

551 AAATGTATGGGTGGTGTCTTCCCTCCCCTAGCCCAGCTAGTAGGGGCCTT

601 TGACGTAGTATGGTGGTGAAAATAGTACACAAAACCCCCCCTCCGTCTGA $<<<<<<<<<<<<<<<<<<<($ PO2R) 651 ACGTTGCCTGCATGGAGCCTGGACGGGGCGCCCTCCCTAACAAAGAAAAC
701 CCCCCCCCCCCCTTTTTTTTAGACCCTCGGATCAGGTAGGGATACCCG 751 CGTGA

Fig. 2. Primer binding sites within the internal transcribed spacer (ITS) region (A) and specific sequences within the consensus ITS sequence from 144 isolates of Phymatotrichopsis omnivora (B). Primer binding site sequences are in bold and underlined (overlapping sites are double underlined) and primer names and directions appear below sequences. Variable positions in the consensus sequence are shaded. 
primer set showed high sensitivity with genomic DNA (1 fg) and plasmid DNA (100 ag). When $1 \mathrm{ng}$ of either cotton or alfalfa genomic DNA was added to each reaction, the observed cycle threshold $(\mathrm{Ct})$ values in the presence of host plant DNA were similar to the $P$. omnivora genomic sensitivity assays' $\mathrm{Ct}$ values, indicating that host genomic DNA did not interfere with real-time PCR assays (Table 5).

Validation of PCR assays. P. omnivora isolation. Eleven pure cultures of $P$. omnivora were isolated from 210 root pieces obtained from the 37 symptomatic samples of cotton and alfalfa obtained from the field.

P. omnivora end-point PCR primer validation. The three primer sets designed amplified the targeted sequences from genomic DNA of $16 P$. omnivora isolates representing the genetic diversity of $P$. omnivora in Texas, Oklahoma, and Arizona. Four sequenced amplicons showed $99 \%$ identity among them and 95 to $99 \%$ identity to BLASTn results, only closely matching $P$. omnivora accessions (query coverage $P$. omnivora $=100 \%$; next nearest blast hit Rhizina $=39$ to $51 \%$ ).

GTG protocol validation. Out of 37 symptomatic plant samples from the field tested using DNA of suboptimal quality, 13 tested positive with the $P$. omnivora-specific primer set $\mathrm{PO} 2 \mathrm{~F} / \mathrm{PO} 2 \mathrm{R}$ (Table 2), while 27 produced amplicons with the universal primer set ITS4/ITS5. The DNA sequences of all the PCR products were obtained and blasted against the GenBank nucleotide database. No false positives or false negatives were produced by primer set $\mathrm{PO} 2 \mathrm{~F} / \mathrm{PO} 2 \mathrm{R}$. All the sequences obtained with the $P$. omnivoraspecific primers matched $P$. omnivora accessions in GenBank; while DNA sequences obtained with the universal ITS primers either confirmed $P$. omnivora infection or matched the host plant (Medicago sativa) or other fungi (Alternaria arborescens, A. alternata, Aspergillus terreus, or Paecilomyces sp.).

$M G T G$ protocol validation. Out of 148 field plant samples that were tentatively identified as infected, a total of 109 were positive for $P$. omnivora using primer set PO3F/PO2R (Table 3). Fifteen asymptomatic plants (Deport $2 \mathrm{G}$ and $2 \mathrm{~N}$ ) collected next to wilted plants from Field 4, Red River Co., Texas, were negative for $P$. omnivora.

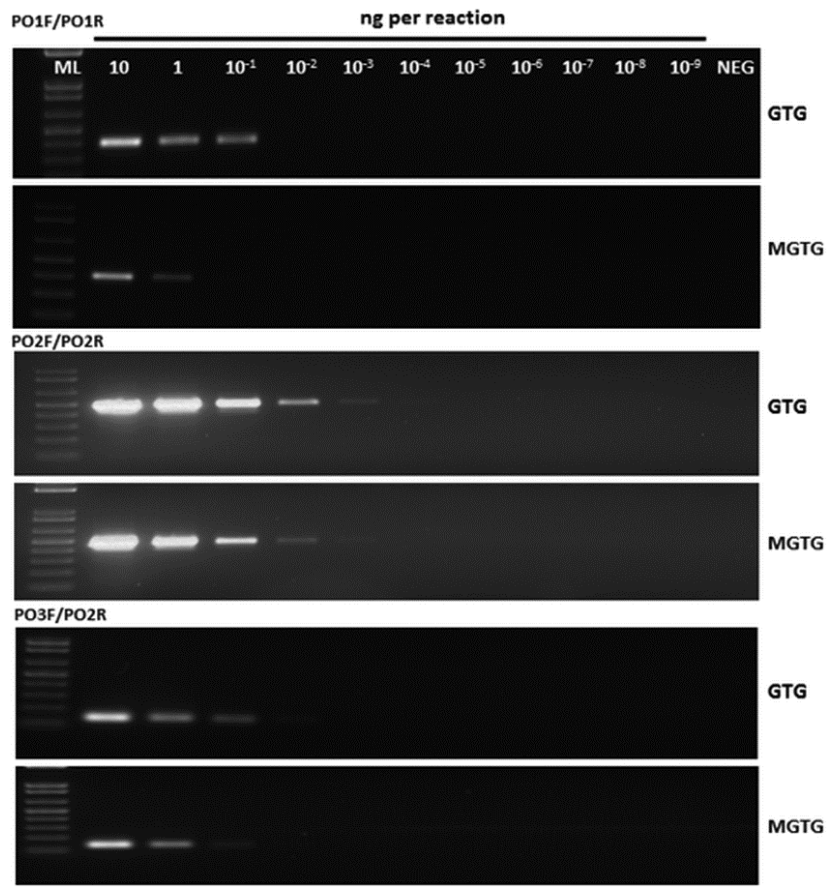

Fig. 3. End-point polymerase chain reaction (PCR) sensitivity test using the three primer sets with the standard Promega GoTaq Green Master Mix protocol (GTG) or the modified Promega GoTaq Green Master Mix protocol (MGTG) and 10-fold serial dilution of Phymatotrichopsis omnivora genomic DNA at the indicated concentrations per reaction. Lane ML: 1 kb Plus DNA ladder (Invitrogen).
SYBR Green qPCR protocol validation. The 37 samples of cotton and alfalfa that were symptomatic for Phymatotrichopsis root rot or were at risk for asymptomatic infections were positive for the presence of $P$. omnivora (Table 2). The detection limit of the assay was $2.9 \mathrm{fg}$. DNA samples obtained from healthy alfalfa and cotton plants grown in growth chambers were negative for the presence of $P$. omnivora.

\section{Discussion}

This study describes the development of sensitive and highly specific end-point PCR and SYBR Green real-time qPCR assays for detection of $P$. omnivora. P. omnivora is a destructive soilborne pathogen occurring only in the alkaline calcareous soils of the southwestern United States and northern Mexico. Thus, plants and soils from $P$. omnivora's endemic regions are subject to regulations and quarantines by U.S. and international agencies. Although the symptoms and signs of Phymatotrichopsis root rot are usually conspicuous on cotton, such diagnostic manifestations may be absent or subtle on other hosts, especially perennial hosts such as alfalfa. Also, confirmatory cultures of the pathogen from infested plant tissue are not always possible because $P$. omnivora is difficult to isolate from infected plants (5). Therefore, sensitive diagnostic methods are needed to rapidly and reproducibly detect the $P$. omnivora within roots from field samples.

The multicopy ITS region was selected as the target gene due to its unique sequence, specificity to $P$. omnivora (5), and high copy number per genome $(\sim 1,000$ copies per haploid genome, based on draft genome sequences, S. M. Marek, unpublished results). All primers developed for this study were designed and optimized with regard to compatibility with one another and low tendency to form hairpins. Moreover, all of the primer sets for this study were designed based on the consensus sequence of ITS sequences from diverse isolates of $P$. omnivora isolated from several hosts collected in southern Arizona and Oklahoma, northern Mexico, and much of Texas over 30 years (21). While the aligned ITS sequences used were diverse, all primers bound within regions conserved across all sequences, as confirmed by successful amplification of PCR products from genomic DNA of 16 diverse P. omnivora isolates from Texas, Oklahoma, and Arizona. Primer sets were specific for $P$. omnivora, with no PCR products amplified from genomic DNA isolated from any of the other soilborne fungi and oomycetes tested, including the closely related fungus, Rhizina undulata

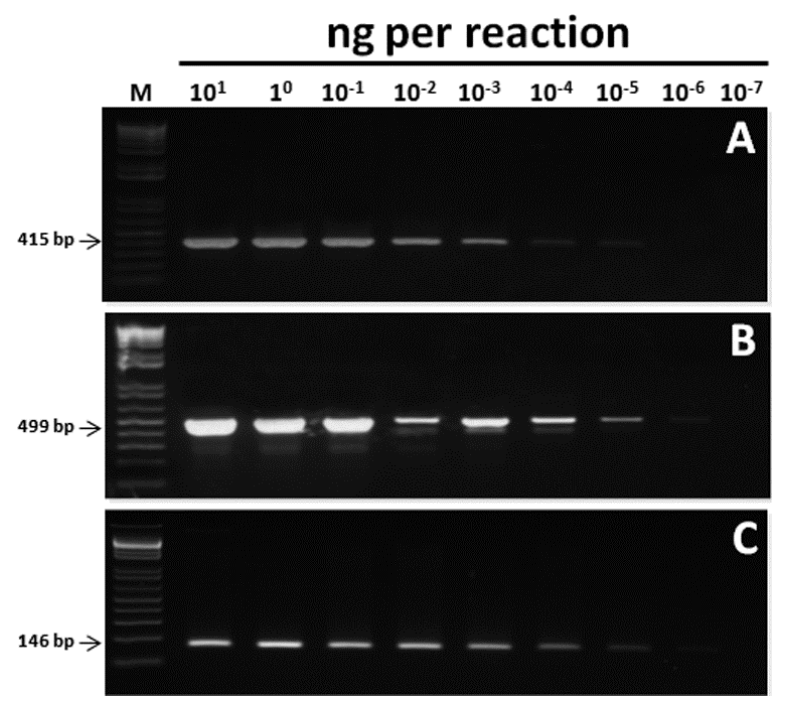

Fig. 4. End-point polymerase chain reaction (PCR) sensitivity of the three primer sets with a 10 -fold serial dilution at the indicated concentration per reaction of plasmid DNA carrying the corresponding PCR products amplified from Phymatotrichopsis omnivora with primer sets A, P01F/P01R, B, PO2F/PO2R, and C, PO3F/PO2R. Lane M: 1 kb Plus DNA ladder (Invitrogen). The band produced by PO2F/PO2R using $10 \mu \mathrm{g}$ template DNA looks faint due to a pipetting error while loading the PCR product on the agarose gel. 
(confamilial with $P$. omnivora in Rhizinaceae). The primers also did not amplify products from DNA isolated from healthy plant samples, or soil collected in Stillwater, OK, which is outside of $P$. omnivora's endemic range.

The described primer sets can be used in end-point PCR assays, and one set, PO3F/PO2R, can also be used in SYBR Green qPCR assays. Primer set $\mathrm{PO} 2 \mathrm{~F} / \mathrm{PO} 2 \mathrm{R}$ was the most sensitive for endpoint $\mathrm{PCR}$, since it detected the target sequence in $100 \mathrm{fg}$ genomic DNA from $P$. omnivora, and $1 \mathrm{fg}$ of plasmid DNA carrying the respective target sequence, and as little as $29 \mathrm{fg} P$. omnivora genomic DNA from infected roots. The sizes of amplicons produced by primer pair $\mathrm{PO} 2 \mathrm{~F} / \mathrm{PO} 2 \mathrm{R}(\sim 564 \mathrm{bp})$ make these suitable for direct sequencing for assay confirmation. The SYBR Green qPCR assay using primers PO3F/PO2R detected the $P$. omnivora target sequences at concentrations down to $1 \mathrm{fg}$ genomic DNA from cultured mycelium, $2.9 \mathrm{fg}$ DNA from infected plant roots, and 100 ag plasmid DNA carrying the cloned amplicon. Thus, the SYBR Green qPCR assay was 100fold more sensitive than the end-point PCR assay using primer set $\mathrm{PO} 2 \mathrm{~F} / \mathrm{PO} 2 \mathrm{R}$ in the detection of $P$. omnivora genomic DNA alone, and at least 10 -fold more sensitive in the detection of $P$. omnivora using DNA from infected plants, in spite of the presence of PCR inhibitors in the samples analyzed.

Remarkably, the $1 \mathrm{fg}$ detection limit for P. omnivora genomic DNA using SYBR Green qPCR equates with detecting six to seven haploid nuclei, assuming the $150 \mathrm{bp}$ ITS target occurs as 1,000 copies per genome equivalent and $1 \mathrm{fg} \approx 978 \mathrm{kbp}(10)$. Such sensitive detection could be used to quantify in planta growth of $P$. omnivora during the asymptomatic phases of infection in susceptible and resistant hosts, as demonstrated in other pathosystems, such as late blight of potato and apple scab $(9,19)$. The described PCR and qPCR assays were tested on numerous infected and healthy plant samples collected from agricultural fields. The assays successfully detected $P$. omnivora in roots from cotton and alfalfa plants displaying symptoms and signs of Phymatotrichopsis root rot and occasionally detected the fungus in healthy-appearing roots from infested fields. These asymptomatic roots could have been in the initial or latent stages of disease development. The modified endpoint PCR protocol detected P. omnivora in $73.6 \%$ of infected field samples using primer sets $\mathrm{PO} 3 \mathrm{~F} / \mathrm{PO} 2 \mathrm{R}$. By comparison, cultural confirmation of $P$. omnivora usually requires numerous attempts to isolate a pure culture from surface-sterilized root pieces with approximately $0.05 \%$ of pieces producing axenic cultures.

The standard GoTaq Master mix protocol was 10 times more sensitive than the modified protocol; however, the modified protocol allowed much shorter runs, which may be convenient for routine diagnostics from mycelial strands or mycelium, or from highquality infected plant DNA. In order to assess the robustness of the described protocols for routine plant sample processing, where samples of variable DNA concentrations and containing PCR in- hibitors must be analyzed, we compared the efficiency of primer set $\mathrm{PO} 2 \mathrm{~F} / \mathrm{PO} 2 \mathrm{R}$ in standard end-point $\mathrm{PCR}$ reactions and primer set $\mathrm{PO} 3 \mathrm{~F} / \mathrm{PO} 2 \mathrm{R}$ in SYBR Green $\mathrm{qPCR}$ to detect $P$. omnivora on symptomatic alfalfa and cotton plant samples showing varying levels of deterioration, using DNA samples obtained with DNA isolation kits without further purification or dilution. The end-point PCR protocol detected P. omnivora in only 13 of 37 (35\%) samples, while the SYBR Green qPCR protocol using diluted DNA detected $P$. omnivora in all 37 infected samples. The presence of alfalfa or cotton genomic DNA or PCR inhibitors derived from host plant tissues did not appear to reduce the sensitivity of the SYBR green qPCR assay; while the end-point PCR assay's sensitivity was severely affected. Good quality DNA should be used in the end-point PCR assay, particularly when working with known recalcitrant host samples. Because of these limitations, PCR primer set $\mathrm{PO} 2 \mathrm{~F} / \mathrm{PO} 2 \mathrm{R}$ is recommended for sensitive detection of $P$. omnivora using the GTG end-point PCR protocol with high-quality DNA samples obtained from infected plants when qPCR is not available, and for identity confirmation of pure cultures of $P$. omnivora or mycelial strands obtained from infected plants using either the GTG or the MGTG protocols. Primer set PO3F/PO2R is recommended for highly sensitive detection of $P$. omnivora using SYBR green qPCR, regardless of the quality of the DNA samples, but can also be used for end-point PCR, with either the GTG or the MGTG protocols, using high-quality fungal or infected plant DNA samples.

Phymatotrichopsis root rot can occur as well-defined rings of dead plants in fields of perennial hosts, such as alfalfa, or late in the season in fields of annual hosts, such as cotton and soybean. However, earlier in the season (summer) the disease begins as several wilted and dead plants adjacent in a row (13). As aboveground disease symptoms are not apparent until the main taproot and/or crown have been girdled, early diagnosis is not likely. In addition, low soil moisture and cool temperatures can inhibit fungal growth and disease expression, even though the fungus persists in the soil and on roots $(16,30)$. The reported SYBR green qPCR assay could make early field diagnosis possible and facilitate preemptive application of the recently described fungicide, flutriafol, with activity against $P$. omnivora (12).

The reported PCR-based detection assays are sensitive, cost effective, quick, and efficient tools that can be used in the routine diagnosis of Phymatotrichopsis root rot and may permit diagnosis of plants lacking characteristic symptoms and signs. This study reports the first fully validated end-point PCR assays for detection of $P$. omnivora and a SYBR Green $\mathrm{qPCR}$ protocol with a primer set 10 times more sensitive than those previously described (5). In addition to routine diagnostics, potential applications of these assays include assessment of $P$. omnivora soil inoculum levels to predict a field's disease potential, monitoring of the pathogen's survival during crop rotations with

Table 5. Comparison of quantitative polymerase chain reaction (qPCR) sensitivity with different templates ${ }^{\mathrm{a}}$

\begin{tabular}{lcccc}
\hline & \multicolumn{4}{c}{ Average Ct values (three replicates) } \\
\cline { 2 - 5 } Template conc. per reaction & Target DNA in plasmid & $\begin{array}{c}\text { Phymatotrichopsis } \\
\text { omnivora }\end{array}$ & $\begin{array}{c}\text { P. omnivora genomic DNA } \\
\text { with cotton genomic DNA }\end{array}$ & $\begin{array}{c}\text { P. omnivora genomic DNA } \\
\text { with alfalfa genomic DNA }\end{array}$ \\
\hline $1 \mathrm{ng}$ & 10.62 & 15.09 & 15.42 & 15.40 \\
$100 \mathrm{pg}$ & 13.33 & 18.48 & 18.59 & 18.62 \\
$10 \mathrm{pg}$ & 14.93 & 21.94 & 21.58 & 21.77 \\
$1 \mathrm{pg}$ & 17.40 & 25.67 & 24.84 & 27.38 \\
$100 \mathrm{fg}$ & 21.06 & 28.97 & 28.03 & 29.29 \\
$10 \mathrm{fg}$ & 24.27 & 32.11 & 30.80 & $\mathrm{~N} / \mathrm{A}$ \\
$1 \mathrm{fg}$ & 27.56 & 34.43 & $\mathrm{~N} / \mathrm{A}$ & $\mathrm{N} / \mathrm{A}$ \\
$100 \mathrm{ag}$ & 30.38 & Not detected & 0.999 & 0.985 \\
$\boldsymbol{R}^{\mathbf{2}}$ & 0.991 & 0.996 & 1.10 & 1.23 \\
$\mathbf{E x}$ & 1.23 & 1.01 & -3.098 & -2.876 \\
$\mathbf{Y}$ & -2.871 & -3.297 & \\
\hline
\end{tabular}

${ }^{a} \mathrm{Ct}$ (cycle threshold), $R^{2}$ (linear correlation), Ex (reaction efficiency), and Y (slope) values obtained in sensitivity assays with primer pair PO3F/PO2R using dilutions of plasmid DNA containing PCR product, $P$. omnivora isolate EC358-C05-4 genomic DNA alone or with $1 \mathrm{ng}$ alfalfa or cotton genomic DNA. $\mathrm{N} / \mathrm{A}=$ data not available, since those concentrations were not tested. 
nonhosts, and evaluation of fungal growth on resistant germplasm used in breeding programs. The described assays could also be used in regulatory agricultural biosecurity and in microbial forensic applications.

\section{Acknowledgments}

This work was supported in part by grants from the Oklahoma State Regents for Higher Education, NSF-EPSCoR, the Oklahoma Department of Agriculture, Food and Forestry, and by the Oklahoma Agricultural Experiment Station Projects OKL02536 to Stephen Marek, OKL02698 to Carla Garzón, and OKL02773 to Francisco Ochoa-Corona. We thank Jacque Fletcher and John Damicone (OSU), for reviewing this manuscript; Madhavi Dhulipala, James N. Enis, Sandrine Casanova, Tim Samuels, Ian Moncrief, Carrie Smith, Kihyuck Choi, Francisco Flores, Chelsea Shafley, Christen Shelton, Johanna Takach, Stormy Posey, Andrea Medina, Gabriela Garcés, Pablo Espinosa, Fernanda Proaño, and Omar Arias for technical assistance; and Nathan Walker, Terry Pitts, Shane Osborne, Clay Jones, Thomas Thiltgen, Michael Morrow, Tom Isakeit, Kevin Ong, Mark Black, James E. Marek, Barry Pryor, and Randy Norton for help sampling. We extend our appreciation to Rimvydas Vasaitis (Swedish University of Agricultural Sciences) for providing Rhizina undulata apothecia used for validation of the techniques developed in this study, and to Jennifer Olson and Hassan Melouk (Oklahoma State University), and Gary Moorman (The Pennsylvania State University) for providing Rhizoctonia, Sclerotinia, and Pythium isolates, respectively. The mention of trade names or commercial products in this publication does not imply recommendation or endorsement by Oklahoma State University.

\section{Literature Cited}

1. Abd-Elmagid, A., Garrido, P. A., Hunger, R., Lyles, J. L., Mansfield, M. A., Gugino, B. K., Smith, D. L., Melouk, H., and Garzon, C. D. 2013. Discriminatory simplex and multiplex PCR for four species of the genus Sclerotinia. J. Microbiol. Methods 92:293-300.

2. Alkan, N., Gadkar, V., Coburn, J., Yarden, O., and Kapulnic, Y. 2004. Quantification of the arbuscular mycorrhizal fungus Glomus intraradices in host tissue using real-time polymerase chain reaction. New Phytol. 161:877-885.

3. Allen, S. J. 1995. Plant quarantine and diseases of cotton. Australas. Plant Pathol. 24:70-73.

4. Altschul, S. F., Gish, W., Miller, W., Myers, E. W., and Lipman, D. J. 1990. Basic local alignment search tool. J. Mol. Biol. 215:403-410.

5. Arif, M., Fletcher, J., Marek, S. M., Melcher, U., and Ochoa-Corona, F. M. 2013. Development of a rapid, sensitive, and field-deployable razor ex biodetection system and quantitative PCR assay for detection of Phymatotrichopsis omnivora using multiple gene targets. Appl. Environ. Microbiol. 79:2312-2320.

6. Arikawa, E., Sun, Y., Wang, J., Zhou, Q., Ning, B., Dial, S. L., Guo, L., and Yang, J. 2008. Cross-platform comparison of SYBR Green real-time PCR with TaqMan PCR, microarrays and other gene expression measurement technologies evaluated in the MicroArray Quality Control (MAQC) study. BMC Genomics 9:1-12.

7. Bustin, S. A. 2005. Real-time, fluorescence-based quantitative PCR: A snapshot of current procedures and preferences. Expert Rev. Mol. Diagnostics (5):493-498.

8. California Department of Food and Agriculture. 2012. Ozonium Root Rot. Page 3261 in: Plant Quarantine Manual. CDFA.

9. Daniels, B., De lantsheer, A., Dreesen, R., Davey, M. W., and Keulmans, J. 2012. Real-time PCR as a promising tool to monitor growth of Venturia spp. in scab-susceptible and -resistant apple leaves. Eur. J. Plant Pathol. 134:821-833

10. Dolezel, J., Bartos, J., Voglmayr, H., and Greilhuber, J. 2003. Nuclear DNA content and genome size of trout and human. Cytometry 51:127-128.

11. EPPO, C. a. Phymatotrichopsis omnivora. Pages 1-5 in: Data Sheets on Quarantine Pests. EPPO.

12. Isakeit, T., Minzenmayer, R. R., and Abrameit, A. 2010. Flutriafol for control of cotton root rot, caused by Phymatotrichopsis omnivora. (Abstr.) Phytopathology 100:S54.

13. Jeger, M. J., Kenerley, C. M., and Gerik, T. J. 1987. Spatial dynamics of Phymatotrichum root rot in row crops in the Blackland region of north central Texas. Phytopathology 77:1647-1656.
14. Karsai, A., Muller, S., Platz, S., and Hauser, M. 2002. Evaluation of a homemade SYBR Green I reaction mixture for real-time PCR quantification of gene expression. BioTechniques 32:790-796.

15. Kenerley, C. M., and Jeger, M. J. 1992. Fungal diseases of the root and stem. Pages 161-190 in: Cotton Diseases. R. J. Hillocks, ed. CAB International, UK.

16. Kenerley, C. M., and Jeger, M. J. 1990. Root colonization by Phymatotrichum omnivorum and symptom expression of Phymatotrichum root rot in cotton in relation to planting date, soil temperature and soil water potential. Plant Pathol. 39:489-500.

17. Kim, J. S., Lee, G. G., Kim, J., Kwon, J. Y., and Kwon, S. T. 2008. The development of rapid real-time PCR detection system for Vibrio parahaemolyticus in raw oyster. Lett. Appl. Microbiol. 46:649-654.

18. Larkin, M. A., Blackshields, G., Brown, N. P., Chenna, R., McGettigan, P. A., McWilliam, H., Valentin, F., Wallace, I. M., Wilm, A., Lopez, R. Thompson, J. D., Gibson, T. J., and Higgins, D. G. 2007. ClustalW2 and ClustalX version 2. Bioinformatics 23:2947-2948.

19. Llorente, B., Bravo-Almonacid, F., Cvitanich, C., Orlowska, E., Torres, H. N., Flawia, M. M., and Alonso, G. D. 2010. A quantitative real-time PCR method for in planta monitoring of Phytophthora infestans growth. Lett. Appl. Microbiol. 51:603-610.

20. Maeda, H., Fujimoto, C., Haruki, Y., Maeda, T., Kokeguchi, S., Petelin, M., Arai, H., Tanimoto, I., Nishimura, F., and Takashiba, S. 2003. Quantitative real-time PCR using TaqMan and SYBR Green for Actinobacillus actinomycetemcomitans, Porphyromonas gingivalis, Prevotella intermedia, tetQ gene and total bacteria. FEMS Immunol. Med. Mic. 39:81-86.

21. Marek, S. M. 2009. Phylogeography of the cotton root rot fungus Phymatotrichopsis omnivora. (Abstr.) Phytopathology 99:S79.

22. Marek, S. M., Hansen, K., Romanish, M., and Thorn, R. G. 2009. Molecular systematics of the cotton root rot pathogen, Phymatotrichopsis omnivora. Persoonia 22:63-74.

23. Martin, R. R., James, D., and Lévesque, C. A. 2000. Impacts of molecular diagnostic technologies on plant disease management. Annu. Rev. Phytopathol. 38:207-239.

24. Moorman, G. W., Kang, S., Geiser, D. M., and Kim, S. H. 2002. Identification and characterization of Pythium species associated with greenhouse floral crops in Pennsylvania. Plant Dis. 86:1227-1231.

25. OEPP/EPPO. 2011. EPPO A1 and A2 Lists of Pests Recommended for Regulation as Quarantine Pests. Pages 16. European and Mediterranean Plant Protection Organization, Paris, France.

26. Pammel, L. H. 1888. Root rot of cotton, or cotton blight. Texas Agric. Exp. Stn. Bull. 4:3-18.

27. Pammel, L. H. 1889. Cotton root-rot. Texas Agric. Exp. Stn. Bull. 7:5-30.

28. Pellissier, F., Glogowski, C. M., Heinemann, S. F., Ballivet, M., and Ossipow, V. 2006. Lab assembly of a low-cost, robust SYBR Green buffer system for quantitative real-time polymerase chain reaction. Anal. Biochem. 350:310-312.

29. Rozen, S., and Skaletsky, H. J. 2000. Primer3 on the WWW for general users and for biologist programmers. Pages 365-386 in: Bioinformatics Methods and Protocols: Methods in Molecular Biology. S. A. M. S. Krawetz, ed. Humana Press, Totowa, NJ.

30. Rush, C. M., Gerik, T. J., and Lyda, S. D. 1984. Factors affecting symptom appearance and development of Phymatotrichum root rot of cotton. Phytopathology 74:1466-1469.

31. Streets, R. B., and Bloss, H. E. 1973. Phymatotrichum root rot. Monogr. American Phytopathological Society 8:38.

32. United Nations. 1995. Plan for Future Ongoing Monitoring and Verification of Iraq's Compliance with Relevant Parts of Section C of Security Council Resolution 687 (1991). Report of the Secretary-General (s/22871/rev.1). Revised Annexes II, III and IV. .

33. Uppalapati, S. R., Young, C. A., Marek, S. M., and Mysore, K. S. 2010. Phymatotrichum (cotton) root rot caused by Phymatotrichopsis omnivora: Retrospects and prospects. Mol. Plant Pathol. 11:325-334.

34. White, T. J., Bruns, T., Lee, S., and Taylor, J. 1990. Amplification and direct sequencing of fungal ribosomal RNA genes for phylogenetics. Pages 315322 in: PCR Protocols: A Guide to Methods and Applications. M. A. Innis, D. H. Gelfand, J. J. Sninsky, and T. J. White, eds. Academic Press, San Diego, CA.

35. Zuker, M. 2003. Mfold web server for nucleic acid folding and hybridization prediction. Nucleic Acids Res. 31:3406-3415. 